Article

\title{
Reproductive Success and Inbreeding Differ in Fragmented Populations of Pinus rzedowskii and Pinus ayacahuite var. veitchii, Two Endemic Mexican Pines under Threat
}

\author{
Paty Castilleja Sánchez ${ }^{1}$, Patricia Delgado Valerio ${ }^{2, *}$, Cuauhtémoc Sáenz-Romero ${ }^{3}$ \\ and Yvonne Herrerías Diego ${ }^{1}$ \\ 1 Laboratorio de Vida Silvestre, Facultad de Biología, Universidad Michoacana de San Nicolás de Hidalgo, \\ Av. Francisco J. Mujica S/N, Ciudad Universitaria, Morelia, Michoacán CP 58030, Mexico; \\ pscastilleja@gmail.com (P.C.S.); yonnediego@gmail.com (Y.H.D.) \\ 2 Laboratorio de Genética, Facultad de Agrobiología, Universidad Michoacana de San Nicolás de Hidalgo, \\ Av. Revolución Esquina con Berlin S/N, Colonia Viveros, Uruapan, Michoacán CP 60170, Mexico \\ 3 Instituto de Investigaciones Agropecuarias y Forestales, Universidad Michoacana de San Nicolás de \\ Hidalgo, A. San Juanito Itzicuaro S/N, Colonia San Juanito Itzicuaro, Morelia, Michoacán CP 58330, Mexico; \\ csaenzromero@gmail.com \\ * Correspondence: dvalerio@umich.mx; Tel./Fax: +52-452-523-6474
}

Academic Editors: Fei-Hai Yu and Timothy A. Martin

Received: 19 June 2016; Accepted: 15 August 2016; Published: 18 August 2016

\begin{abstract}
Seed production, quality, germination and seedling establishment are indicators of reproductive success in conifers. Monitoring of these parameters is essential to determine the viability of populations for the purposes of conservation. We analyze cone and seed traits as indicators of reproductive success in the endangered Rzedowski's pine (Pinus rzedowskii (Madrigal et Caballero) and near-threatened veitchii pine (Pinus ayacahuite var. veitchii (Shaw)) in west-central Michoacán, Mexico. These traits were systematically quantified and their variation assessed using Generalized Linear Mixed Models (GLMMs). We found that the reproductive success of Rzedowski's pine seems to be critical, presenting low seed efficiency $(17.10 \%)$, germination $(5.0 \%)$ and seedling establishment $(27.7 \%)$, with high levels of inbreeding $(0.79)$. In contrast, veitchii pine presents moderate seed efficiency $(54.9 \%)$, high germination $(71.5 \%)$ and seedling establishment ( $84 \%-97 \%)$ and low inbreeding (0.33). Reproductive indicators differed significantly among zones and populations for each species, where fragment sizes mainly affected seed production and efficiency. This result indicates that fragmentation has played a more important role in the reproductive success of Rzedowski's pine than in veitchii pine, perhaps by limiting pollen flow among zones and populations and producing higher levels of inbreeding and lower seed efficiency in the former species. We propose a conservation strategy for these important pine species in order to increase their long-term genetic viability.
\end{abstract}

Keywords: Pinus; reproductive indicators; inbreeding index; fragmentation; conservation

\section{Introduction}

Fragmentation and habitat degradation due to natural disturbance regimes and increasing anthropogenic land use changes have caused the natural populations of plants to become smaller and isolated and subjected to negative genetic and demographic consequences [1,2]. Habitat fragmentation promotes a reduction of gene flow between populations, allele loss through the effect of genetic drift and increased levels of inbreeding [2-4]. The adaptive potential of species is disrupted with the substantial reduction of their reproductive success (e.g., lower seed production, fruit set, viability, 
germination and seedling establishment, Mitton [5]; Nason and Hamrick [6]). This negative effect is present regardless of habitat type, environmental conditions, ecological interactions and life history traits of the species $[7,8]$. For example, habitat fragmentation decreases population sizes and increases the distance between remnant patches, causing significant limitations to the dispersion of seeds and pollen among these patches [9-11]. Similarly, in habitats of small size and low density, there will be low levels of outcrossing, where each tree is pollinated by its own pollen and only partly pollinated by pollen from neighboring trees, thus increasing the levels of inbreeding [5]. Variation in environmental conditions, such as the light, temperature, wind, soil and altitude, can also affect fruit and seed production [12,13]. An appropriate evaluation of reproductive indicators is therefore necessary in order to: (i) assess the viability of natural populations; (ii) select regions for seed production; (iii) preserve natural genetic resources; and (iv) develop management and conservation programs for each species.

In conifers, part of the process of successful reproduction has been commonly studied through cone and seed indicators, i.e., the developed seeds, number of filled seeds per cone, aborted ovules per cone and seed efficiency [14-20]. Assessment of germination and seed viability has also been used to determine reproductive success at species and population levels $[15,16]$. However, there are few studies of reproductive indicators in Mexico for species of the genus Pinus: P. pseudostrobus and P. montezumae [18], P. leiophylla [18,21,22], P. cembroides [23], P. catarinae and P. johannis [24,25] and most of the studies have focused on widely distributed species. Only two studies have addressed endangered species with narrow distributions (e.g., P. catarinae and P. johannis). Further studies incorporating species of restricted distribution and small populations are therefore required.

The present study focuses on several cone and seed reproductive indicators in two Mexican endemic pines; Rzedowski's pine ( $P$. rzedowskii Madrigal et Caballero), listed as in danger of extinction [26,27], and veitchii pine (P. ayacahuite var. veitchii Shaw), listed as near threatened [27]. Both species have narrow distributions and are represented by small, fragmented and low-density populations. In the case of Rzedowski's pine, general studies of their demographic status reported the existence of only 17 small populations (2000-3500 individuals), with a low rate of recruitment and contrasting female cone production, $4-150$ cones per tree $[28,29]$. At the molecular level, isozyme surveys have revealed intermediate levels of genetic variation, highly structured populations and significant levels of inbreeding [30]; these demographic and genetic conditions may affect the reproductive success of these species. The populations of veitchii pine, while distributed throughout several states of central Mexico (10-15 populations; Martinez [31]; Aguirre et al. [32]), are fragmented and present relatively few individuals per population. Only one study of seed production exists for the two populations distributed in Estado de México, in Mexico, and the authors reported 158 developed seeds per cone [33]. Currently, no genetic and demographic studies of this variety have been formally reported. Interestingly, these species are the only representatives of soft pines distributed in Michoacán state and, as a consequence, they are completely isolated from other soft pines.

The purpose of the present study is to determine the effect of forest fragmentation on reproductive success in Rzedowski's and veitchii pine. Specifically, we evaluate certain reproductive indicators (such as number of fertile cone scales, seed potential, developed seeds, aborted ovules, filled seeds and seed efficiency), levels of inbreeding, germination and seedling establishment for each species. We then compare six reproductive indicators (developed seeds, aborted ovules of first and second year, empty and filled seeds and seed efficiency) among species, zones and populations, and determine whether developed seeds, empty seeds, filled seeds and seed efficiency increase with population size or geographic distance. Finally, we discuss other hypotheses regarding the observed reproductive patterns and propose a conservation strategy for these important pine species in order to increase their long-term genetic viability. 


\section{Materials and Methods}

\subsection{Study Species and Sampling}

The distribution of Rzedowski's pine is restricted to a single region at Coalcoman, Michoacán, in Mexico (in the Sierra Madre del Sur). All of the known populations (17) of Rzedowski's pine were visited between December 2012 and March 2013, while only the five populations of veitchii pine reported in Michoacán state were visited between October and November 2013. These populations are located near the town of La Palma, within the remnant cloud forest (Table 1, Figure 1).

Due to the rugged topography of the terrain and the variation population size, three different sampling schemes were employed [29]: In most populations, an altitudinal transect was established for the upper part of a slope towards the lower part of the distribution area (e.g., 8. Fresno (FR), 12. Aguacatera (AG), 13. J. Ortiz (JO), and 14. Magueyera (MA) for Rzedowski's pine, and 1. Antena (AN), 3. Ojo de A. (OA) and 4. Pedregal (PE) for veitchii pine). For the most accessible populations (e.g., populations, 9. Alberca (AL), 10. Varaloso (VA), 11. Pinabete (PI) and 15. Carretilla (CR) of Rzedowski's pine), ten sampling points were established, comprising eight on the population margins and two in the central part of the formed polygon. In the smaller populations (less than 100 individuals; e.g., 1. Chiqueritos (CH), 2. Soledad (SO), 3. El Durazno (DU) and 17. Canoyita (CA) of Rzedowski's pine, and 2. Mesa (ME) and 5. Vigas (VI) of veitchii pine), all trees were inspected.
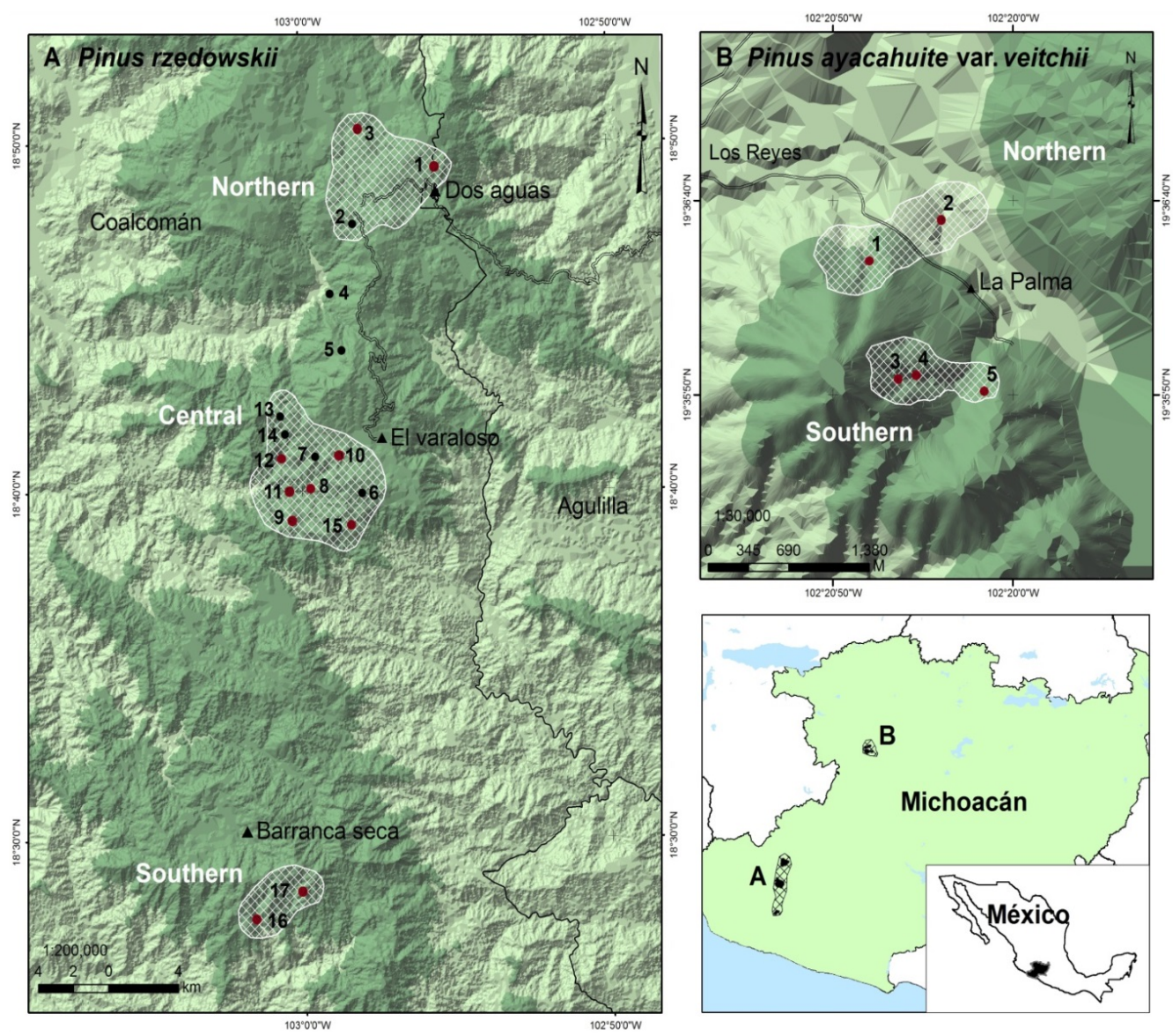

Figure 1. Geographical location of two pine species studied in Michoacán, Mexico: (A) three zones of Pinus rzedowskii populations (northern, central and southern); and (B) two zones of P. ayacahuite var. veitchii populations (northern and southern). The red circles indicate the populations for which cones were collected. The numbers denote the population code as described in Table 1. 
Table 1. General data regarding the geographical locations of Pinus rzedowskii and P. ayacahuite var. veitchii populations in Michoacán, Mexico.

\begin{tabular}{|c|c|c|c|c|c|c|}
\hline \multirow{2}{*}{ Species } & \multirow{2}{*}{$\begin{array}{c}\text { Zone } \\
\text { Population }\end{array}$} & \multicolumn{2}{|c|}{ Geographic Location } & \multirow{2}{*}{$\begin{array}{l}\text { Altitude } \\
\text { (m.a.s.l.) }\end{array}$} & \multicolumn{2}{|c|}{ Population } \\
\hline & & Latitude & Longitude & & Area (ha) & Size $(N)$ \\
\hline \multirow[t]{7}{*}{ Pinus rzedowskii } & Northern (small size) & & & & & \\
\hline & 1. Chiqueritos* $(\mathrm{CH})$ & $18^{\circ} 49^{\prime} 17^{\prime \prime}$ & $102^{\circ} 59^{\prime} 36^{\prime \prime}$ & 2380 & 1 & 60 \\
\hline & 2. Soledad (SO) & $18^{\circ} 47^{\prime} 40^{\prime \prime}$ & $102^{\circ} 58^{\prime} 17^{\prime \prime}$ & 2434 & 1 & 9 \\
\hline & 3. El Durazno * (DU) & $18^{\circ} 50^{\prime} 24^{\prime \prime}$ & $102^{\circ} 58^{\prime} 04.2^{\prime \prime}$ & 2089 & 1 & 15 \\
\hline & 4. Tabernas (TA) & $18^{\circ} 45^{\prime} 90^{\prime \prime}$ & $102^{\circ} 59^{\prime} 02^{\prime \prime}$ & 2300 & 1 & 4 \\
\hline & 5. Tejamanil (TE) & $18^{\circ} 44^{\prime} 02^{\prime \prime}$ & $102^{\circ} 58^{\prime} 40^{\prime \prime}$ & 2194 & 1 & 1 \\
\hline & & & & Total & 5 & 99 \\
\hline \multirow[t]{12}{*}{ Pinus rzedowskii } & Central (large size) & & & & & \\
\hline & 6. Vaca pinta (VP) & $18^{\circ} 39^{\prime} 56^{\prime \prime}$ & $102^{\circ} 58^{\prime} 03^{\prime \prime}$ & 2149 & 1 & 200 \\
\hline & 7. Predio Varaloso (PV) & $18^{\circ} 41^{\prime} 09^{\prime \prime}$ & $102^{\circ} 58^{\prime} 48^{\prime \prime}$ & 2480 & 7 & 200 \\
\hline & 8. Fresno * (FR) & $18^{\circ} 40^{\prime} 04^{\prime \prime}$ & $102^{\circ} 59^{\prime} 43^{\prime \prime}$ & 2450 & 116 & 3500 \\
\hline & 9. Alberca * $(\mathrm{AL})$ & $18^{\circ} 39^{\prime} 09^{\prime \prime}$ & $103^{\circ} 00^{\prime} 19^{\prime \prime}$ & 2094 & 58 & 2340 \\
\hline & 10. Varaloso * (VA) & $18^{\circ} 40^{\prime} 39^{\prime \prime}$ & $102^{\circ} 54^{\prime} 34^{\prime \prime}$ & 2392 & 77 & 2300 \\
\hline & 11. Pinabete * $(\mathrm{PI})$ & $18^{\circ} 39^{\prime} 59^{\prime \prime}$ & $103^{\circ} 00^{\prime} 24^{\prime \prime}$ & 2340 & 39 & 2340 \\
\hline & 12. Aguacatera * $(\mathrm{AG})$ & $18^{\circ} 40^{\prime} 56^{\prime \prime}$ & $103^{\circ} 00^{\prime} 40^{\prime \prime}$ & 1714 & 34 & 1714 \\
\hline & 13. Jesus Ortiz (JO) & $18^{\circ} 42^{\prime} 9.4^{\prime \prime}$ & $103^{\circ} 00^{\prime} 41.4^{\prime \prime}$ & 2395 & 37 & 1500 \\
\hline & 14. Magueyera (MA) & $18^{\circ} 41^{\prime} 38.2^{\prime \prime}$ & $103^{\circ} 00^{\prime} 32.2^{\prime \prime}$ & 2223 & 28 & 2000 \\
\hline & 15. Carretilla * (CR) & $18^{\circ} 39^{\prime} 01^{\prime \prime}$ & $102^{\circ} 58^{\prime} 24.4^{\prime \prime}$ & 2119 & 3 & 300 \\
\hline & & & & Total & 400 & 16,394 \\
\hline \multirow[t]{4}{*}{ Pinus rzedowskii } & Southern (medium size) & & & & & \\
\hline & 16. Huarache * (HU) & $18^{\circ} 27^{\prime} 42.9^{\prime \prime}$ & $103^{\circ} 01^{\prime} 37.5^{\prime \prime}$ & 1631 & 67 & 3000 \\
\hline & 17. Canoyita * (CA) & $18^{\circ} 28^{\prime} 30.0^{\prime \prime}$ & $103^{\circ} 00^{\prime} 07.1^{\prime \prime}$ & 2219 & 50 & 500 \\
\hline & & & & Total & 117 & 3500 \\
\hline \multirow[t]{4}{*}{ Pinus ayacahuite var. veitchii } & Northern (small size) & & & & & \\
\hline & 1. Antena * (AN) & $19^{\circ} 36^{\prime} 28.6^{\prime \prime}$ & $102^{\circ} 20^{\prime} 37.1^{\prime \prime}$ & 2200 & 30 & 3000 \\
\hline & 2. Mesa * (ME) & $19^{\circ} 36^{\prime} 39.1^{\prime \prime}$ & $102^{\circ} 20^{\prime} 24^{\prime \prime}$ & 2150 & 3 & 200 \\
\hline & & & & Total & 33 & 3200 \\
\hline \multirow[t]{5}{*}{ Pinus ayacahuite var. veitchii } & Southern (large size) & & & & & \\
\hline & 3. Ojo de Agua. * (OA) & $19^{\circ} 35^{\prime} 55.4^{\prime \prime}$ & $102^{\circ} 20^{\prime} 6.9^{\prime \prime}$ & 2300 & 23 & 7500 \\
\hline & 4. Pedregal * $(\mathrm{PE})$ & $19^{\circ} 35^{\prime} 55.2^{\prime \prime}$ & $102^{\circ} 20^{\prime} 27.8^{\prime \prime}$ & 2350 & 67 & 2000 \\
\hline & 5. Vigas * $(\mathrm{VI})$ & $19^{\circ} 35^{\prime} 54.0^{\prime \prime}$ & $102^{\circ} 20^{\prime} 32.2^{\prime \prime}$ & 2200 & 11 & 2100 \\
\hline & & & & Total & 101 & 11,600 \\
\hline
\end{tabular}

* Sites from which cones were collected; meters above sea level (m.a.s.l.). Population area (ha), and population size ( $N$; number of individuals) taken from Delgado [29] and Delgado et al. [28].

The study areas were divided into zones according to the distribution and population size of each species (we considered a zone to be a cluster of natural populations): three zones for Rzedowski's pine (northern: small-size; central: larger-size; and southern: medium-size) and two zones for veitchii pine (northern: small-size; and southern: larger-size) (Figure 1). For each species, population and zone sizes were obtained from the studies conducted by Delgado [29] for Rzedowski's pine, and Delgado et al. [28] for veitchii pine (see Table 1). The number of selected trees and collected cones varied according to the presence of reproductive trees with no apparent damage by insect pests or fungi (Table 1). Damage to cones or seeds caused by this type of organism has not been reported in these pine species.

We inspected between 1 and 32 individuals of Rzedowski's pine per population with a total of 328 trees, as well as 3 to 30 individuals of veitchii pine per populations with a total of 70 individuals across five populations. Inspected reproductive trees within populations were a minimum of $50 \mathrm{~m}$ apart, in order to reduce the probability of parentage [34]. For Rzedowski's pine, only 1-3 cones were recovered per tree in 10 populations (from a total of 17 populations inspected), producing a total of 38 cones from 21 individual trees. In the case of the veitchii pine (where all of the populations had trees with cones), 3-6 cones were collected per tree in five populations, producing a total of 53 cones from 22 individual trees. Cones were placed into individual paper bags for each parent tree at the time of collection, until subsequent processing. 


\subsection{Reproductive Indicators}

Eight measures of reproductive success were calculated per cone as follows: (1) The number of fertile scales per cone (FS); these were found in the central third of the cone and contained one or two developed seeds with mature seed coats, whereas infertile scales occur at the apex and the base of the cone and never bear seeds [14]. (2) Seed potential per cone (SP); the biological limit of seeds that a cone can produce, determined as the total number of fertile scales multiplied by two (because any scale has the capacity to produce two seeds; Bramlett et al. [14]). (3) Percentage of first year aborted ovules per cone (OA1); these are potential seeds that abort during the first growing season, they are identified as small and rudimentary ovules adhered to the base of the winds after the first year of development. This was determined as the ratio of first year aborted ovules to seed potential per cone per 100. Two specific causes have been documented; pollination failure and predation by seedbugs [14,35]. (4) Percentage of second year aborted ovules per cone (OA2); these are ovules that aborted during the second growing season; they are pollinated but the fertilization process does not occur. They are identified as resinous, flattened and collapsed ovules, some of which produce a small seed coat but are not as large as a fully developed seed. This was estimated as the ratio of second year aborted ovules per cone to the seed potential per 100. Some causes of this type of ovules are predation by seedbugs on the developing cone [36] and damage by moisture or nutritional stress during development [14,37-40]. (5) Number of developed seeds per cone (DS); the total number of seeds with enlarged seed coats, whether filled or empty, is equal to the number of fertilized ovules and thus is an estimate of the amount of pollen received [41]. (6) Number of empty seeds per cone (EMS); these are mature seed coats that do not contain an embryo, the seeds have some remnants of gametophyte or embryo tissue or have a damaged embryo. The principal causes of this seed class are environmental stress such as low temperatures, pests and diseases (seedbug and fungi) and inbreeding, either through self-pollination or through crossing with relatives [14,41]. (7) Number of filled seeds per cone (FS); these have potential to germinate; they have healthy, undamaged gametophyte tissue, a normal embryo and no evidence of fungi or other destructive pests. Filled and empty seeds were identified using the flotation method by submerging the developed seed in a solution with distilled water and Captan ${ }^{\circledR}$ (Bayer, Distrito Federal, Mexico) $(3 \mathrm{~g} / \mathrm{L}$ ) for four hours in the case of ayacahuite pine and $24 \mathrm{~h}$ for the Rzedowki's pine. The density of seeds of the latter pines is low and they therefore required more time to soak. All seeds floating after that time were considered empty, while those that had sunk were considered filled. X-ray verification was conducted on 20 seeds (view Figure 2). (8) Percentage of seed efficiency per cone (SE); defined as the ratio of filled seeds to the seed potential per 100. Thus, seed efficiency measures the productivity of filled seeds in a cone in relation to its biological capacity or seed potential (SP). This is the single most important measure of seed viability production [14].

An inbreeding index was estimated using the proportion of empty seeds over the total number of developed seeds (a proxy of inbreeding depression; Mosseler et al. [15]), at the levels of species and zones. Higher values, close to " 1 " in this index, indicate higher inbreeding. This index is based on several studies of controlled self-pollination, the majority of which showed that the number of empty seeds was the result of the deleterious genetic effects of inbreeding on the development of embryos. Inbreeding may lead to inbreeding depression with negative effects not only on embryo development, but also on seed germination and seedling survival [20,37-40].

Seed germination was tested using samples of 15-100 seeds per tree, depending on cone production and number of filled seeds per tree (380 seeds from 21 trees for Rzedowski's pine and 1200 seeds from 22 trees for veitchii pine). The seeds were placed on filter paper in Petri dishes for a period of eight days at $5{ }^{\circ} \mathrm{C}$ with constant moisture (distilled water and Captan solution ${ }^{\circledR} ; 3 \mathrm{~g} / \mathrm{L}$ ), as a stratification treatment. The seeds were kept at room temperature until germination took place, with records kept of each individual seed. Seed germination was evaluated daily, from the day of sowing until a period of 30 days had elapsed, recording the total number of seeds germinated per day. Percentage of germination was estimated by dividing the number of germinated seeds by the total number of filled seeds and multiplying the result by 100 [14,42]. 
(A) Pinus ayacahuite var. veitchii

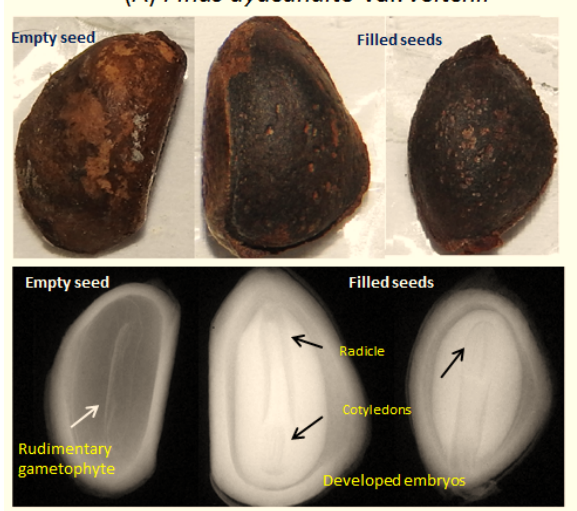

(B) Pinus rzedowskii

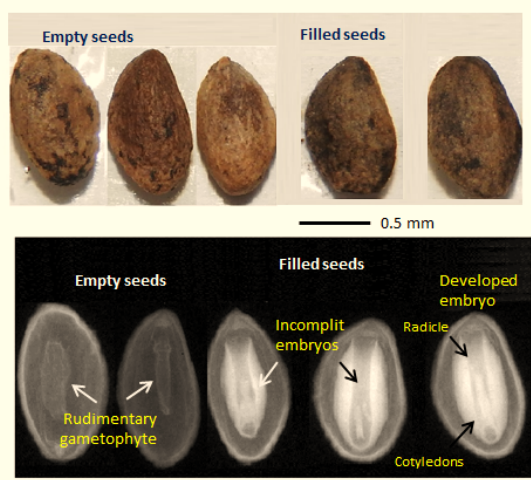

Figure 2. Radiographic images of developed seeds: (A) Ayacahuite pine seeds, showing empty seeds with rudimentary gametophyte and filled seeds with completely developed embryons; and (B) Rzedowski's pine seeds, showing empty seeds with rudimentary gametophyte and filled seeds with non-fully developed embryo and completely developed embryo.

The viable seedlings obtained, were transplanted a nursery for subsequent evaluation of seedling establishment under field conditions. Eighteen Rzedowski's seedlings (all of the seedlings obtained) and 642 seedling of veitchii pine (a subsample of the 1200 seedlings obtained) were planted in quadrants measuring $3 \mathrm{~m} \times 3 \mathrm{~m}$ in the field. Seedling survival after planting was evaluated at 6 and 12 months after planting (February 2015 and August 2015, respectively). Percentage of seedling establishment was obtained by dividing the number of plants remaining alive by the total number of seedlings planted and multiplying the result by 100 [42].

\subsection{Data Analysis}

We conducted a Generalized Linear Mixed Model (GLMM) analysis to determine whether there were significant differences among species, zones and populations for six reproductive indicators (number of fertile cone scales, developed seeds, aborted ovules of first and second year, filled seeds and seed efficiency). The GLMM had populations nested in zones with the latter nested in species. We called this the overall model. Because the number of populations per zone as well as the number of trees that actually yielded seeds per population differed widely between species, we ran a second reduced model per species in order to identify differences among zones and among populations within zones, but this time per species. The zones and populations were considered as random effects and species as a fixed effect. The model probabilities were estimated using a restricted maximum likelihood (REML) algorithm [43]. We used a Tukey-Kramer (HSD; Miller [44]) multiple-mean comparison test to determine which zones contributed most to the observed variation. Tests were performed with a significance level of $\alpha=0.05$. All statistical analyses were conducted using SAS version 9.3 [45].

To determine the existence of associations between size populations and four reproductive indicators (developed seeds, filled seeds, empty seeds and seed efficiency), Pearson's correlation coefficients $(r)$ were performed for all populations of each species. Similarly, in order to determine the effect of geographic distance on the same four indicators between pairs of populations, we performed a Mantel Test with 1000 permutations [46]. Both analyses were conducted using PAST Statistics software v. 3.04 [47].

\section{Results}

\subsection{Reproductive Indicator}

The values of fertile scales, seed potential, developed seeds and filled seeds were lower in Rzedowski's pine than in veitchii pine (Table 2). The proportions of aborted ovules were very similar 
in both species, where aborted ovules were greater in the second year than in the first year (Table 2). Rzedowski's pine showed a mean seed efficiency per cone (defined as the difference between the number of filled seeds and seed potential) of $17.10 \%$, i.e., $82.90 \%$ of seed losses by presence of empty seeds and aborted ovules. In contrast, the mean seed efficiency of veitchii pine was three times higher at $54.90 \%$ (only $45.10 \%$ of seed losses).

Large differences between the two species can be clearly appreciated according to the inbreeding index, with values of 0.79 for Rzedowski's pine and 0.33 for veitchii pine (higher values close to " 1 " in this inde, indicate higher inbreeding). For both species, the highest values ( 0.85 and 0.48 for Rzedowski's pine and veitchii pine, respectively) were obtained in the northern zones.

Seed germination varied between species $(p<0.001)$. Most seeds germinated between the sixth and tenth days in veitchii pine, and between 11 and 15 days in Rzedowski's pine. Germination percentages for Rzedowski's pine were extremely low ( $5 \%, 18$ seedlings), with the highest value observed in the central region (3\%). Veitchii pine, however, showed a relatively high germination percentage $(71.5 \%$, 858 seedlings), with the highest values observed in the southern zone (68.4\%) (Figure 3).

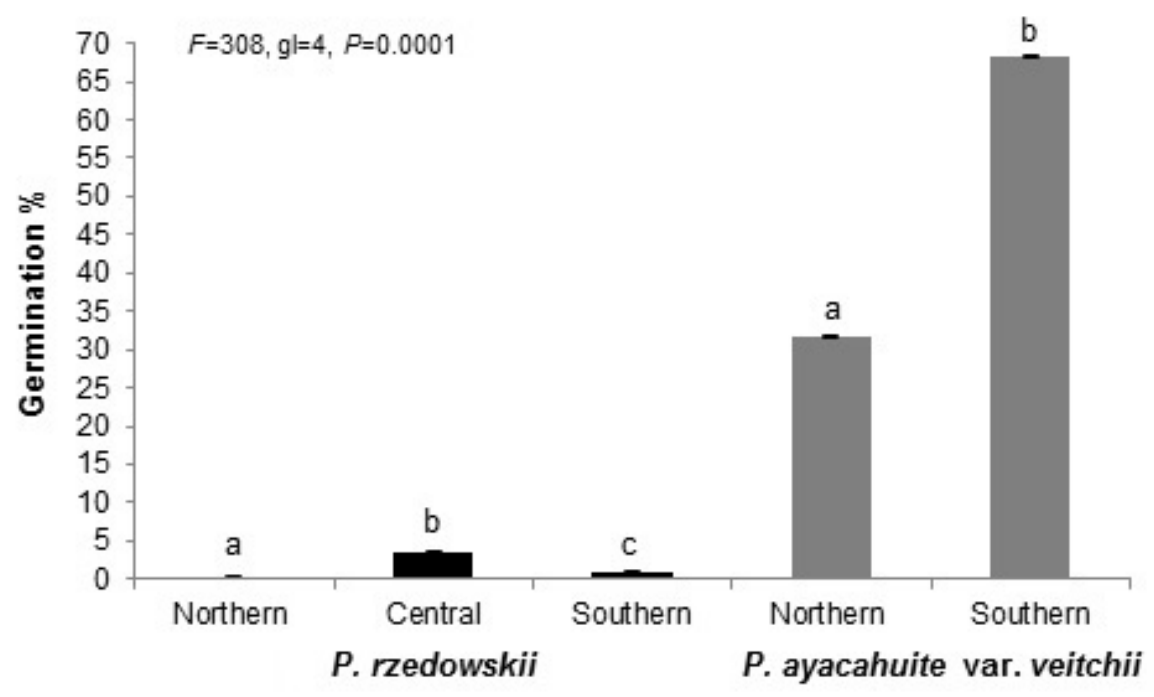

Figure 3. Germination percentages of $P$. rzedowskii and P. ayacahuite var. veitchii in different study zones. Vertical lines over each bar represent \pm one standard error. Letters indicate statistical grouping within each species, based on $\alpha=0.05$.

Establishment of plants of Rzedowski's pine was very low, with only $27.7 \%$ ( 5 seedlings) for the two periods measured. For veitchii pine, however, establishment was $97 \%$ ( 590 seedlings) at 6 months and $84 \%$ (539 seedlings) at 12 months from the beginning of the experiment.

\subsection{Reproductive Indicators Variation}

The number of developed, empty and filled seeds, as well as seed efficiency, showed pronounced differences among species, zones and populations. In contrast, the number of aborted ovules did not differ significantly among species, zones or populations (Table 3). In the zones of Rzedowski's pine, the differences were highly significant $(p<0.001)$ in the developed seeds, empty seeds and seed efficiency, with filled seeds presenting only a marginally significant difference $(p<0.037)$. In veitchii pine, differences in filled seeds and seed efficiency were highly significant $(p<0.002)$, while developed seeds were only slightly determinant $(p<0.022)$ and empty seeds did not differ $(p=0.975)$. 
Table 2. Least square means and standard error $( \pm \mathrm{SE})$ for cone and seed reproductive indicators of P. rzedowskii and P. ayacahuite var. veitchii, zones.

\begin{tabular}{|c|c|c|c|c|c|c|c|c|c|}
\hline \multirow{2}{*}{ Species } & \multirow{2}{*}{ Zone } & \multirow{2}{*}{$\begin{array}{l}\text { Fertile Scales } \\
\text { Number }\end{array}$} & \multirow{2}{*}{ Seed Potential } & \multirow{2}{*}{$\begin{array}{c}\text { Developed } \\
\text { Seeds Number }\end{array}$} & \multirow{2}{*}{$\begin{array}{c}\text { Empty Seeds } \\
\text { Number }\end{array}$} & \multirow{2}{*}{$\begin{array}{l}\text { Filled Seeds } \\
\text { Number }\end{array}$} & \multicolumn{2}{|c|}{ Aborted Ovules (\%) } & \multirow{2}{*}{ Seed Efficiency (\%) } \\
\hline & & & & & & & First Year & Second Year & \\
\hline \multirow{4}{*}{ Pinus rzedowskii } & Northern & $\begin{array}{l}39.50 \\
(1.40)\end{array}$ & $\begin{array}{l}79.06 \\
(2.79)\end{array}$ & $\begin{array}{l}61.82 \\
(4.41)\end{array}$ & $\begin{array}{c}52.70 \\
(5.5)\end{array}$ & $\begin{array}{c}9.10 \\
(1.52)\end{array}$ & $\begin{array}{c}7.1 \\
(2.33)\end{array}$ & $\begin{array}{l}15.50 \\
(4.13)\end{array}$ & $\begin{array}{l}11.51 \\
(2.63)\end{array}$ \\
\hline & Central & $\begin{array}{l}24.20 \\
(1.12)\end{array}$ & $\begin{array}{l}48.35 \\
(2.25)\end{array}$ & $\begin{array}{l}37.12 \\
(3.55)\end{array}$ & $\begin{array}{l}24.60 \\
(2.18)\end{array}$ & $\begin{array}{l}12.53 \\
(1.22)\end{array}$ & $\begin{array}{c}5.80 \\
(1.87)\end{array}$ & $\begin{array}{l}18.10 \\
(3.32)\end{array}$ & $\begin{array}{l}25.91 \\
(2.12)\end{array}$ \\
\hline & Southern & $\begin{array}{l}21.10 \\
(1.45)\end{array}$ & $\begin{array}{l}42.20 \\
(2.93)\end{array}$ & $\begin{array}{l}33.60 \\
(4.60)\end{array}$ & $\begin{array}{c}26.20 \\
(2.8) \\
\end{array}$ & $\begin{array}{c}7.40 \\
(1.59)\end{array}$ & $\begin{array}{c}5.3 \\
(1.44)\end{array}$ & $\begin{array}{c}15.1 \\
(4.33)\end{array}$ & $\begin{array}{l}17.53 \\
(2.76)\end{array}$ \\
\hline & Average & 28.20 & 56.53 & 44.16 & 34.50 & 9.67 & 6.10 & 16.24 & 17.10 \\
\hline \multirow{3}{*}{$\begin{array}{l}\text { Pinus ayacahuite } \\
\text { var. veitchii }\end{array}$} & Northern & $\begin{array}{l}31.27 \\
(5.10)\end{array}$ & $\begin{array}{c}62.55 \\
(10.21)\end{array}$ & $\begin{array}{c}39.36 \\
(12.75)\end{array}$ & $\begin{array}{l}13.73 \\
(5.85)\end{array}$ & $\begin{array}{l}25.64 \\
(5.71)\end{array}$ & $\begin{array}{l}11.76 \\
(2.43)\end{array}$ & $\begin{array}{l}25.00 \\
(5.18)\end{array}$ & $\begin{array}{l}42.80 \\
(5.45)\end{array}$ \\
\hline & Southern & $\begin{array}{l}46.38 \\
(2.61)\end{array}$ & $\begin{array}{l}92.76 \\
(5.22)\end{array}$ & $\begin{array}{l}73.17 \\
(6.52)\end{array}$ & $\begin{array}{l}13.55 \\
(2.51)\end{array}$ & $\begin{array}{c}59.62 \\
(5.8)\end{array}$ & $\begin{array}{c}7.47 \\
(1.24)\end{array}$ & $\begin{array}{l}13.55 \\
(2.65)\end{array}$ & $\begin{array}{l}65.90 \\
(2.79)\end{array}$ \\
\hline & Average & 38.82 & 77.65 & 56.25 & 13.64 & 42.63 & 9.6 & 19.27 & 54.90 \\
\hline
\end{tabular}

Table 3. Summary of the General Lineal Mixed Model to test differences among cone and seed reproductive indicators between P. rzedowskii and P. ayacahuite var. veitchii species (overall model) and differences among zones and among populations within zones (one model per species).

\begin{tabular}{|c|c|c|c|c|c|c|c|c|c|c|c|c|}
\hline \multirow[b]{3}{*}{ Source } & \multirow{2}{*}{\multicolumn{2}{|c|}{ Developed Seeds (No.) }} & \multirow{2}{*}{\multicolumn{2}{|c|}{ Empty Seeds (No.) }} & \multirow{2}{*}{\multicolumn{2}{|c|}{ Filled Seeds (No.) }} & \multicolumn{4}{|c|}{ Aborted Ovules (\%) } & \multirow{2}{*}{\multicolumn{2}{|c|}{ Seed Efficiency (\%) }} \\
\hline & & & & & & & \multicolumn{2}{|c|}{ First Year } & \multicolumn{2}{|c|}{ Second Year } & & \\
\hline & $F_{\text {-value }}$ & $p$ & $F_{\text {-value }}$ & $p$ & $F_{\text {-value }}$ & $p$ & $F_{\text {-value }}$ & $p$ & $F_{\text {-value }}$ & $p$ & $F_{\text {-value }}$ & $p$ \\
\hline Species & 8.98 & 0.003 & 25.41 & 0.001 & 59.93 & 0.001 & 2.71 & 0.103 & 0.82 & 0.368 & 134.51 & 0.001 \\
\hline \multicolumn{13}{|l|}{ P. rzedowskii } \\
\hline Zone & 12.51 & 0.001 & 21.70 & 0.001 & 3.62 & 0.037 & 0.16 & 0.849 & 0.20 & 0.821 & 8.89 & 0.001 \\
\hline Population (zone) & 3.28 & 0.008 & 5.84 & 0.001 & 4.15 & 0.002 & 0.20 & 0.992 & 1.10 & 0.395 & 5.68 & 0.002 \\
\hline \multicolumn{13}{|c|}{ P. ayacahuite var. veitchii } \\
\hline Zone & 5.56 & 0.022 & 0.010 & 0.975 & 10.73 & 0.002 & 3.54 & 0.065 & 3.85 & 0.055 & 14.19 & 0.001 \\
\hline Population (zone) & 3.79 & 0.009 & 2.75 & 0.038 & 4.05 & 0.007 & 1.95 & 0.117 & 3.64 & $0.011^{*}$ & 3.38 & 0.016 \\
\hline
\end{tabular}

At the population level for Rzedowski's pine, the four reproductive indicators were significantly different $(p<0.008)$, whereas in veitchii pine, the developed seeds and filled seeds presented significant differences $(p<0.009)$, and empty seeds and seed efficiency presented a substantial difference $(p<0.038)$ (Table 3); $p=$ probability. 
The Tukey-Kramer multiple-mean comparison test $(\alpha<0.05)$ indicated that the zones that contributed most to the observed variation in Rzedowski's pine were the northern zone for fertile scales and developed seed, and the central zone for filled seeds and seed efficiency (Figure 4). Regarding differences among populations within each zone, for fertile scales and developed seeds indicators in Rzedowski's pine, the population 1.CH of the northern zone was the most differentiated, and for filled seeds and seed efficiency, the 12.AG population at the central zone was the most differentiated. In the case of veitchii pine, the 2.OA population was the most differentiated for all four reproductive indicators, along with 3.PE in the case of seed efficiency. Both of these populations were distributed in the southern zone.
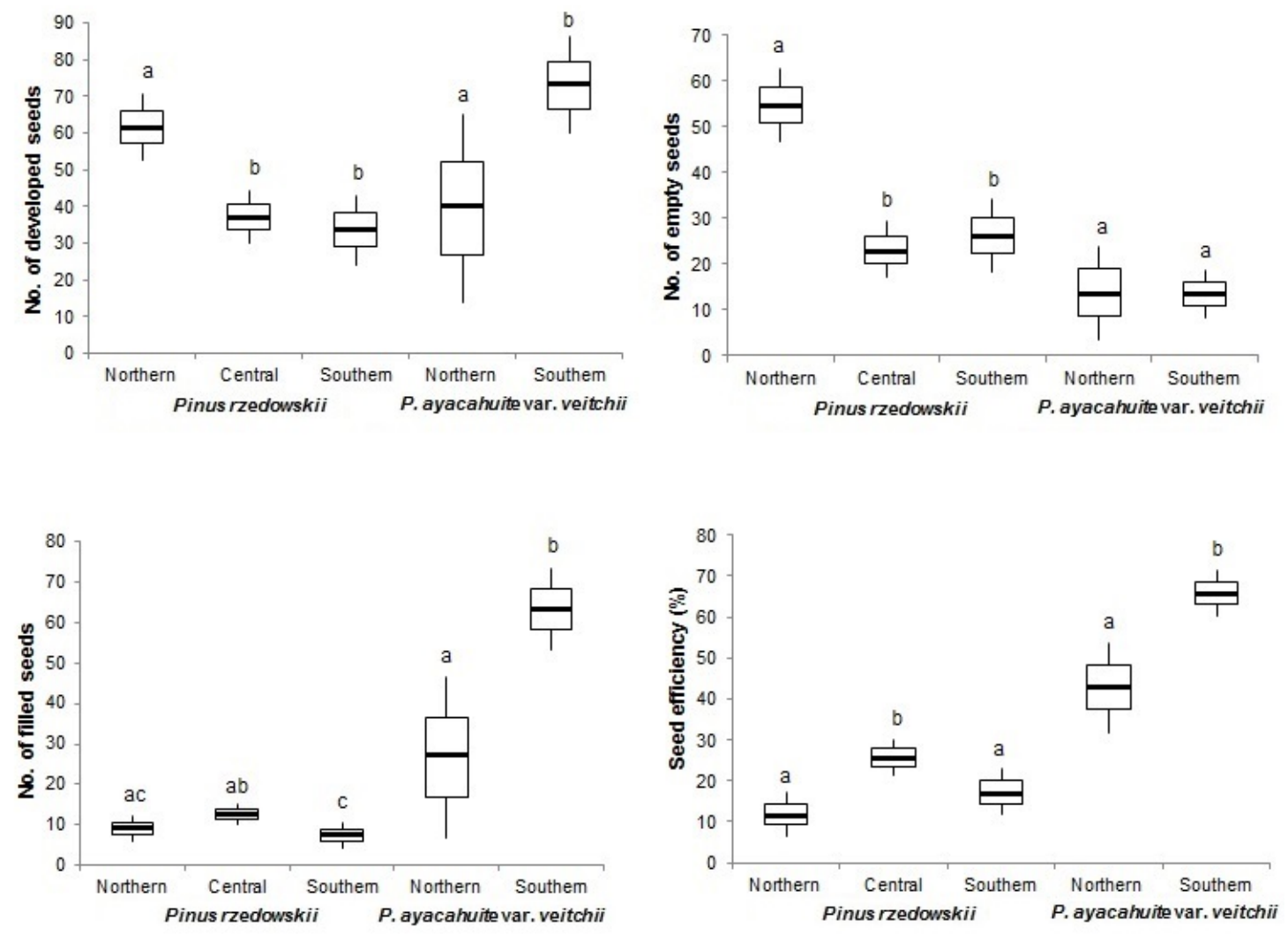

Figure 4. Tukey-Kramer test for the reproductive characteristics of cones and seeds for three zones of Rzedowski's pine and two zones of veitchii pine. Vertical lines over each bar represent \pm standard error. Letters indicate grouping based on $\alpha=0.05$.

\subsection{Reproductive Indicators, Population Size and Geographic Association}

Of the four reproductive indicators that showed significant differences, from Rzedowski's pine, only developed seeds and empty seeds presented a negative and significant association with population size ( $r=-0.676, p=0.032$; and $r=-0.673, p=0.033$, respectively) (Figure 5a,b). None of the four variables showed a significant association with the geographical distribution of their populations. In the case of veitchii pine, seed efficiency presented a positive and significant association with the geographic distribution of the populations $(r=0.693, p=0.035)$ (Figure $4 \mathrm{c})$, but none of the four reproductive indicators correlated significantly with population size. 

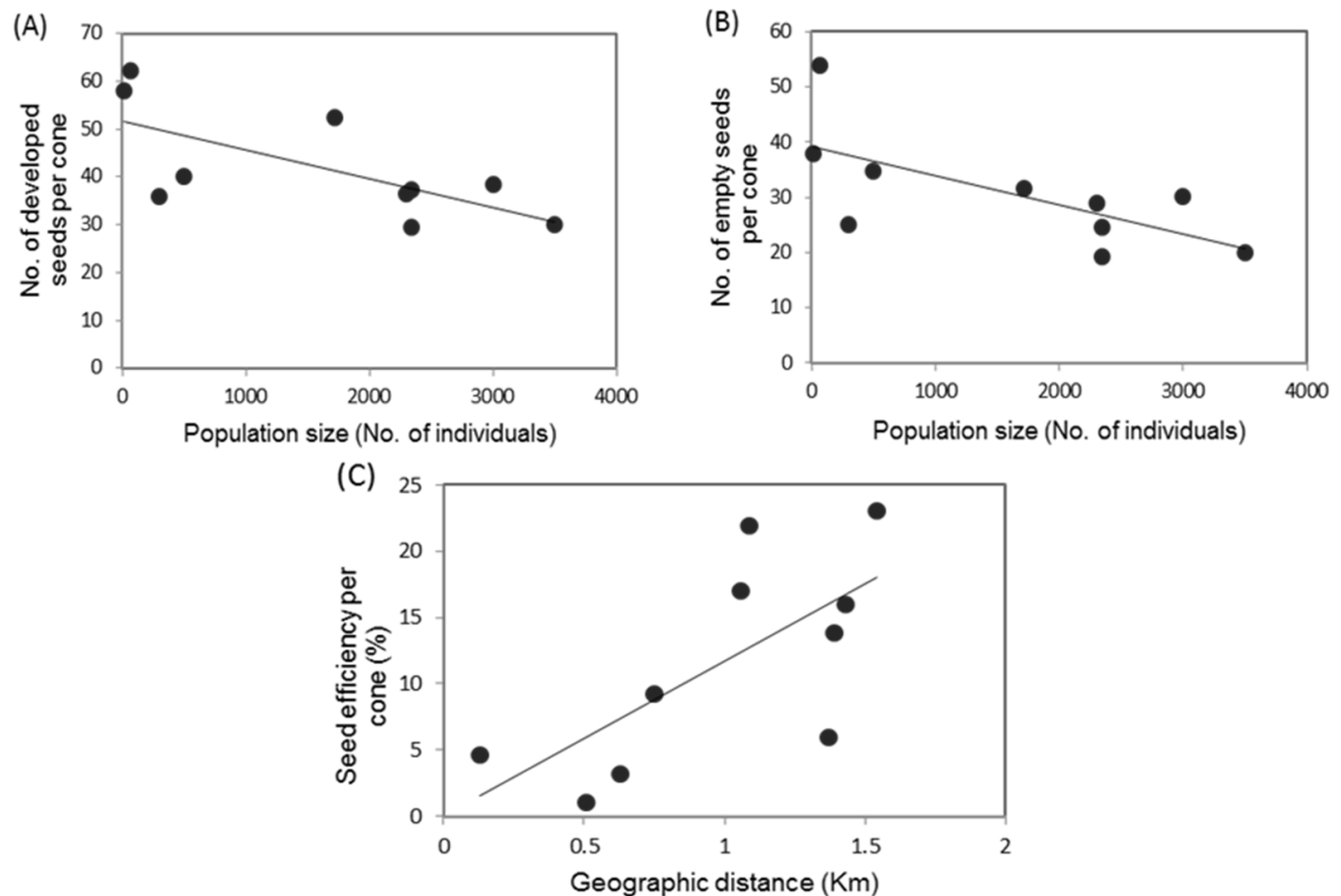

Figure 5. Association of reproductive indicators with population size and geographic distribution. (A) Relationship between population sizes and mean number of developed seeds $(y=-0.006 x+51.657$; $r=-0.676)$; and (B) mean number of empty seeds $(y=-0.0053 x+39.193 ; r=-0.673)$ from Rzedowski's pine. (C) Relationship between seed efficiency and geographic distance in veitchii pine $(Z=232$ out of the 1000 permuted data sets greater than or equal to the original Z-score from the mantel Test).

\section{Discussion}

\subsection{Contrasting Reproductive Indicators}

The results reveal a sharp contrast in seed efficiency, germination percentage and seedling survival between the two species studied. The reproductive success of Rzedowski's pine seems to be critical, since female cone production was only observed in 10 out of 17 populations. Furthermore, the cones of this species presented only 9.67 filled seeds per cone and their seed efficiency was consequently very low $(17.10 \%)$. Results such as these are common among pine species of narrow distribution, with fragmented and isolated populations. For instance, the seed efficiency of $P$. catarinae is $20.9 \%$, with a mean of only two viable seeds per cone [24]. Likewise, the reported seed efficiency for P. johannis, a species confined to a small area in Northern Coahuila, is only $11 \%$ in three of the six populations reported for the species [48]. This pattern is also observed in other conifers: three populations of Picea mexicana distributed along the states of Chihuahua, Nuevo León and Coahuila present $24 \%$ seed efficiency [34], while this value is only 7\% in one extreme-range population of Pseudotsuga menziesii in Estado de México [49].

In contrast with the previous results, veitchii pine showed a relatively high production of developed seeds and filled seeds (56.25 and 42.63, respectively), and much higher seed efficiency per cone than was the case with Rzedowski's pine (mean 54.90\%). This value is similar to those found in species with fragmented populations but of wider distribution and larger population size. A study of the same variety in the Sierra Nevada of Mexico found a seed efficiency of $87 \%$ per cone [33]. Likewise, in a population of $P$. patula in Puebla state, seed efficiency was found to be 75.5\% [50], with $68 \%$ reported for P. montezumae in a Michoacán population [18]. Together, these results suggest large differences among species in terms of reproductive ability and seed efficiency. 
The mean percentage of aborted ovules observed was similar in both species $(22.34 \%$ in Rzedowski's and $28.86 \%$ in veitchii pine), and in other conifer species of restricted distribution (34.2\% for P. johannis, Flores [48]; 34\%-41\% for Pseudotsuga menziesii, Mápula [51]), or with fragmented populations but wider distributions (13.5\%-55\%) for P. engelmanii, Prieto and Trujillo [52] and Bustamante et al. [19]; $18.19 \%$ for P. catariane, Lemus [24]; and 15\% for two veitchii pine population in Sierra Nevada of Estado de México (Huerta [33]). A possible cause of proportion of empty seeds and aborted ovules is inbreeding. The majority of conifers are sexually monoecious and the probability of inbreeding is high [53]. Coniferous pollen can travel over $600 \mathrm{~km}$ [54], while the seeds travel much shorter distances of between 12 and $90 \mathrm{~m}$, depending on size, wing shape and wind direction [55]. This prompts the establishment of groups of trees that are genetically related and promotes crossing among relatives. Therefore, in smaller isolated populations, the probability of mating occurring among relatives is higher than in larger populations that may present sufficient gene flow [5,56,57]. The amount of available pollen for fertilization in small and isolated populations may also cause ovule abortion and empty seeds in two different ways: First, insufficient pollen may increase selfing within individual trees, causing a greater proportion of empty seeds [58]; and second, some of the pollinated ovules will not be fertilized (presence of aborted first-year ovules) or will not develop normally (presence of aborted second-year ovules) $[14,59,60]$. Second-year aborted ovules were more numerous than first-year aborted ovules in both species, but the values of empty seeds and aborted ovules were higher in Rzedowski's pine than in veitchii pine. This suggests that, while pollen flow is likely among neighboring populations, the amount of pollen is insufficient to prevent selfing and there is a consequent occurrence of high seed abortion and/or empty seeds.

In conifers, one of the strongest arguments for the presence of empty seeds is that the effect of inbreeding is present during the different stages of embryo development. The reproductive cycle of pine is two to three years, including differentiation of buds to female cone, pollination (one year) and fertilization of ovules, until seed cone maturity ( 2 or 3 years) $[14,59,60]$. When self-pollination occurs, the production of hormones stimulates ovule development, the seed is coated and the cones can be mature, but the seeds contained within are empty because of the effect of lethal alleles that prevent the normal development of embryos [15,60]. Embryonic degeneration is the result of the increased expression of lethal recessives in line with the increased homozygosity due to inbreeding $[20,41-56,58]$. Thus, with increased levels of selfing, higher numbers of empty seeds are found. This is consistent with the high level of inbreeding found in Rzedowski's pine (0.79), a value that is similar to those recorded in other endangered conifer species $(0.72$ in P. johannis, Flores et al. [47]; 0.60 in P. culminicola, Delgado et al. [28]; 0.84 in Picea mexicana, Flores et al. [24]; and 0.80 in Pseudotsuga menziesii, Mápula et al. [51]). These values contrast with that observed for veitchii pine (0.33), which was similar to the values obtained in two species with fragmented but widely distributed populations (0.35 in P. rigida, Mosseler et al. [16] and 0.50 in P. leiophylla, Gómez et al. [22]).

The extremely low seed germination in Rzedowski's pine $(5 \%)$ and percentage of plants established (27.7\% (13 seedlings) may also be related to high levels of inbreeding. Moreover, $72 \%$ of the seedlings were abnormal (e.g., they lacked radicular germination or presented undeveloped primary needles, deformed stems, etc.), which is indicative of the important effect of inbreeding depression [39]. This mechanism would perhaps act during different developmental stages of the plants, such as embryo development, seed germination and subsequent seedling survival. The results estimated by isozymes in 12 populations confirm the elevated inbreeding coefficient in this pine $\left(F_{I S}=0.214\right)$ [30], where mean gene flow per generation was lower (1.5) than the values reported for other conifer species (usually $>4$, Hamrick et al. [61]). This strongly suggests that little genetic exchange exists among populations and among zones, which is consistent with their geographic fragmentation and isolation. In sharp contrast, seed germination is relatively high in veitchii pine $(71.5 \%)$ and only a few examples of this species presented abnormalities $(0.58 \%$, five seedlings). In addition, plant establishment was high $(84 \%)$, a result that is consistent with the low levels of inbreeding observed. 
Some other factors may influence the reproductive success of Rzedowski's pine, including barriers to gene flow, tree density and the presence of few effective reproductive individuals. The distribution area of this species presents limestone soils and the trees consequently tend to form small isolated patches. Moreover, the terrain has rough slopes with intricate valleys that may serve to impede pollen flow. In addition, most populations have fewer than 500 individuals, which may act to increase the occurrence of mating among relatives [29]. As described above, only 21 reproductive individuals were found, bearing few cones (1-11), which provided a total of 38 cones. These numbers are even lower than those previously found in the same area by Delgado [29]; at that time, this author recorded 37 reproductive trees with 145 cones in total. It should be noted that both of these quantities are still low compared to the average cone production of pines with similar size cones $(8-12 \mathrm{~cm})$ that can reach up to 300 cones per tree $[18,53]$. In addition, observations conducted over three time periods (1993-1995, Delgado [29], 2001-2003 and 2005-2008, Delgado [62]), indicate that a high production of cones was not presented for this species during this time. In contrast, the number of veitchii pine cones per tree was greater than 200 (cone size $23-34 \mathrm{~cm}$, this study; $18-40 \mathrm{~cm}$, Huerta [33]), observing cones from both the first and second year of development on the same trees. It is not clear how many populations of this species are present (10-15, Martinez [31]; Aguirre et al. [32]), but their populations are distributed in Central Mexico (ten times larger than that of the Rzedowski's pine zone) and it is likely that the isolation of the five study populations has been recent, and therefore the isolation is not reflected as an important limitation of pollen flow among these five or other more distant populations. However, the isolation that exists among populations of Rzedowski's pine could be much earlier. For some authors, this species is considered of relictual origin and phylogenetic studies show a basal position on the topologies of the Cembroides group [63-65]. Therefore, the isolation and fragmentation of their populations are important factors that could be affect pollen flow among them.

\subsection{Reproductive Indicators Variation}

The significant differences for reproductive indicators among zones of Rzedowski's pine and veitchii pine appear to be related to the size of the zones. For Rzedowski's pine, the northern zone (which has small population sizes) yielded the highest proportion of empty seeds (85.3\%). In contrast, the highest number of filled seeds, seed efficiency and higher germination were observed in the central zone that has the largest populations. The results at population level presented a similar tendency that among zones. Nevertheless, only the developed seeds and empty seeds showed a negative and significant association with population size, indicating that the small populations produced more seeds per cone than the large populations, but the majority of seeds produced in small populations are empty. Which could be associated with the effect of inbreeding, due to selfing or because the pollination occurred between related trees. A study realized in Picea glauca obtained similar results, where trees in small and medium population sizes produced fewer filled seeds per cone $(38 \%$ and $30 \%$, respectively) than trees within larger stands. These trees receive a larger proportion of self-pollen or pollen from related trees [44]. Veitchii pine in the southern zone, which features larger population sizes, presented the highest values of developed seeds, filled seeds and seed efficiency. In this case, geographic distance was associated with seed efficiency, suggesting that pollination is more effective among distant populations than near populations, decreasing the inbreeding levels in this species.

High variation in reproductive indicators among populations has been observed in some pine species (e.g., P. pinea, Ganatsas et al. [66]; P. patula, Ramírez et al. [50]), Picea genus (e.g., P. rubens, Mosseler et al. [15]; P. mexicana, Flores et al. [34]; and Pseudotsuga macrolepis [49]). In most cases, the results have been attributed to differences in physical and climatic characteristics among sites, including soil type, nutrient levels and synchrony of temperature, wind direction and humidity with aspects of pollination and fertilization. Where the trees are stressed, such as in the case of highly degraded sites or when the trees enter the over-mature phase (senescence), their reproductive output seems to decline, since the cone produces a lower number of filled seeds, many of which lack full development [66]. In the case of our study species, the sites with the highest reproductive success are those with the largest 
areas and highest tree numbers (more than 2000-3000 individuals; Table 1). At these sites, the trees are located on slopes with deep, well-developed soils and high soil moisture levels. The central zone of the distribution of Rzedowski's pine comprises the highest number of reproductive trees (individuals of more than 40 years in age) and contains all age categories (seedlings, juvenile, reproductive adult, mature and senescent adults mostly around 400 years of age; Delgado et al. [30]). Similarly, the veitchii pine of the southern zone is found within a well-preserved remnant of cloud forest [67], where most of the trees are in the reproductive stage ( $<60$ years old). Some trees of Rzedowski's pine distributed in the north and south zones are therefore established in nutrient-poor limestone soils. Forest communities require water and nutrients for growth and seed and cone production [68]. Moreover, the trees of Rzedowski's pine could be assigning energy preferentially to the differentiation of support structures and maintenance, rather than to development of reproductive structures (female and male cones). Such a situation could also influence the production and efficiency of the seeds observed.

\subsection{Conservation Recommendations}

Based on our results, we suggest that the areas where the two species are distributed should be declared nature reserves, and be kept free from human disturbance (such as grazing, land use alteration for agricultural crops and fires) in order to function as natural reservoirs of the gene pool of these species. In the case of Rzedowski's pine, the major problem detected is the low number of filled seeds and efficiency, which has a direct impact on levels of germination and seedling establishment. There should therefore be an emphasis on activities that increase the density of reproductive trees. Thus, it is necessary to implement programs of afforestation with seedlings that originate from the central zone, where the highest production of filled seeds and the lowest level of inbreeding occurs. The central zone could be considered as a Unit of Conservation of Genetic Forestry Resources (UCRGF, by its Spanish acronym), which are natural managed populations with the priority of maintaining the natural genetic variation, and of sufficiently large size to allow the action of evolutionary forces that shape the genetic structure of the populations (mutation, selection, genetic derivation and migration) $[69,70]$. Implementing controlled pollination management, using pollen from the central zone that features higher filled seed production, in order to pollinate the trees of the northern and southern zones and increase the outcrossing rates within and among populations is also highly recommended. Conducting ex situ germplasm conservation (of seeds, pollen, tissues, needles, buds, etc.) that on the one hand allows safeguarding of the genetic resources representative of this species (of all populations), and on the other the possibility of producing plants in vitro, and introducing seedlings to populations other than those from which they originated, in order to increase tree density and effective population size is also advisable.

In veitchii pine, no inbreeding, seed production or seed efficiency problems were detected; however, it is advisable to conduct in situ conservation activities that focus on two aspects: (i) the restoration of fragments through periodical clearing for natural regeneration and seedling establishment; and (ii) seed collection, particularly from the southern zone for plant production, in order to increase population sizes and achieve the spatial and probably genetic connectivity among the remaining five populations. All of the populations should be considered as UCRGF, which allows not only the conservation of genetic resources of this species, but also of other species associated with the remnants of the montane cloud forest in which they are found. In addition, our field observations strongly suggest that the most pressing factor for veitchii pine is the loss of forest caused by increased avocado cultivation. Alternative economic schemes must therefore be formally designed for the forest owners (e.g., commercial plantations for the production of ornamental trees, obtaining pulp for paper production and several other timber applications). All such actions must consider the participation of both local inhabitants and the authorities responsible for safeguarding forest resources in Mexico. 


\section{Conclusions}

While both of the studied species present restricted and isolated distributions, the reproductive indicators are much lower in Rzedowski's pine than in veitchii pine. Rzedowski's pine populations from the central zone of its distribution present the highest reproductive indicator values, including filled seeds, seed efficiency and germination; however, these estimates are much lower than those of veitchii pine and other pine species. The more favorable reproductive performance of veitchii pine might be explained by its more recent fragmentation and isolation compared to Rzedowski's pine. For this last species, fragmentation may have a more ancestral origin, so that the populations have remained isolated for a longer time (restricted to sites with rough slopes and limestone soils), where the flow of pollen is limited and consequently increasing levels of inbreeding and impacting negatively on germination and seedling establishment. In veitchii pine, such effects cannot yet be observed and this has allowed higher reproductive success. This study constitutes a first effort to determine reproductive success in these two species; we therefore consider that it is necessary to conduct supplementary evaluations over various periods of time in order to obtain more robust estimates of the different reproductive indicators. Molecular studies should also be performed in order to evaluate the levels of inbreeding in the parent trees and progeny, rates of outcrossing and estimate the effective size of populations. Such information would further our knowledge regarding the reproductive and evolutionary patterns of these important pine species.

Acknowledgments: We thank Maria Luisa España, Antonio González and Rodolfo Salas for their invaluable comments on earlier versions of the manuscript; Raúl Macias and Melchor De la Cruz for logistic support; the people of the communities of Coalcoman and La Palma for their assistance during fieldwork; Dante Castellanos, Luisa Alvarez, Frecia Ramirezand Agustín Campos for their support in experimental work; Virginia Rebolledo and Jonathan Hernández for their suggestions regarding data analysis; and Keith Macmillan for comments on the manuscript and English revision. We also thank the editors Fei-Hai Yu and Timothy A. Martin and two anonymous reviewers for their critical and pertinent comments. This work was supported by a scholarship awarded to Paty Castilleja (CONACyT-286239) and grants from CONAFOR-CONACYT-176167 and PROFOCIE-2014/2015 awarded to Patricia Delgado.

Author Contributions: Patricia Delgado Valerio and Yvonne Herrerías Diego conceived and designed the study; Patricia Delgado Valerio and Paty Castilleja Sánchez collected the material and implemented the study; Paty Castilleja Sánchez, Cuauhtémoc Sáenz-Romero and Yvonne Herrerías Diego analyzed the data; Patricia Delgado Valerio and Yvonne Herrerías Diego contributed reagents/materials; and Paty Castilleja Sánchez, Patricia Delgado Valerio and Cuauhtémoc Sáenz-Romero wrote the paper.

Conflicts of Interest: The authors declare no conflict of interest.

\section{References}

1. Hedrick, P.W. Conservation genetics: Where are we now? Trends Ecol. Evol. 2001, 16, 629-636. [CrossRef]

2. Frankham, R.; Briscoe, D.A.; Ballou, J.D. Introduction to Conservation Genetics; Cambridge University Press: New York, NY, USA, 2002.

3. Slatkin, M. Gene flow and the geographic structure of natural populations. Science 1987, 236, 787-792. [CrossRef] [PubMed]

4. Ellstrand, N.C.; Elam, D.R. Population genetic consequences of small population size: Implications for plant conservation. Annu. Rev. Ecol. Evol. Syst. 1993, 217-242. [CrossRef]

5. Mitton, J.B. The dynamic mating systems of conifers. New For. 1992, 6, 197-216. [CrossRef]

6. Nason, J.D.; Hamrick, J.L. Reproductive and genetic consequences of forest fragmentation: Two case studies of neotropical canopy trees. J. Hered. 1997, 88, 264-276. [CrossRef]

7. Aguilar, R.; Ashworth, L.; Galetto, L.; Aizen, M.A. Plant reproductive susceptibility to habitat fragmentation: Review and synthesis through a meta-analysis. Ecol. Lett. 2006, 9, 968-980. [CrossRef] [PubMed]

8. Brys, R.; Jacquemyn, H.; Endels, P.; van Rossum, F.; Hermy, M.; Triest, L.; de bruyn, L.; Blust, G.D. Reduced reproductive success in small populations of the self-incompatible Primula vulgaris. J. Ecol. 2004, 92, 5-14. [CrossRef]

9. Rathcke, B.J.; Jules, E.S. Habitat fragmentation and plant-pollinator interactions. Curr. Sci. 1993, 65, 273-277. 
10. Aizen, M.A.; Feinsinger, P. Forest fragmentation, pollination, and plant reproduction in a Chaco dry forest, Argentina. Ecology 1994, 75, 330-351. [CrossRef]

11. Artz, D.R.; Waddington, K.D. The effects of neighbouring tree islands on pollinator density and diversity, and on pollination of a wet prairie species, Asclepias lanceolata (Apocynaceae). J. Ecol. 2006, 94, 597-608. [CrossRef]

12. Hobbs, R.J.; Yates, C.J. Impacts of ecosystem fragmentation on plant populations: Generalising the idiosyncratic. Aust. J. Bot. 2003, 51, 471-488. [CrossRef]

13. Messaoud, Y.; Bergeron, Y.; Asselin, H. Reproductive potential of balsam fir (Abies balsamea), white spruce (Picea glauca), and black spruce (P. mariana) at the ecotone between mixedwood and coniferous forests in the boreal zone of western Quebec. Am. J. Bot. 2007, 94, 746-754. [CrossRef] [PubMed]

14. Bramlett, D.L.; Belcher, E.W.; DeBarr, J.R.; Hertel, J.L.; Karrfalt, R.P.; Lantz, C.W.; Miller, T.; Ware, K.D.; Yates, H.O. Cone Analysis of Southern Pines: A Guidebook; Southeastern Forest Experiment Station, Southeastern Forest, State and Private Forestry: Atlanta, GA, USA, 1977; p. 28.

15. Mosseler, A.; Major, J.E.; Simpson, J.D.; Daigle, B.; Lange, K.; Park, Y.S.; Johnsen, K.H.; Rajora, O.P. Indicators of population viability in red spruce, Picea rubens. I. Reproductive traits and fecundity. Can. J. Bot. 2000, 78, 928-940.

16. Mosseler, A.; Rajora, O.P.; Major, J.E.; Kim, K.H. Reproductive and genetic characteristics of rare, disjunct pitch pine populations at the northern limits of its range in Canada. Conserv. Genet. 2004, 5, 571-583. [CrossRef]

17. Lyons, L.A. The seed production capacity and efficiency of red pine cones Pinus resinosa Ait. Can. J. Bot. 1956, 34, 27-36. [CrossRef]

18. Delgado, V.P. Evaluación de la capacidad productiva y eficiencia de semillas para tres especies del género Pinus (P. montezumae Lamb., P. pseudostrobus Lind. y P. leiophylla Schl. \& Cham.), en la zona boscosa de Nuevo San Juan Parangaricutiro, Michoacán, México. Bol. Soc. Bot. Mex. 1994, 54, 267-274.

19. Bustamante, G.V.; Prieto, R.J.A.; Merlín, B.E.; Alvarez, Z.R.; Carrillo, P.A.; Hernández, D.J.C. Potencial y eficiencia de producción de semilla de Pinus engelmannii Carr., en tres rodales semilleros del estado de Durango, México. Madera Bosques. 2012, 18, 7-21.

20. Williams, C.G.; Barnes, R.D.; Nyoka, I. Embryonic genetic load for a neotropical conifer, Pinus patula Schiede et Deppe. J. Hered. 1999, 90, 394-398. [CrossRef]

21. Morales, V.M.G.; Ramírez, M.C.A.; Delgado, V.P.; López, U.J. Indicadores reproductivos de Pinus leiophylla Schltdl. Et Cham., en la cuenca del río Angulo, Michoacán. Rev. Mex. Cienc. For. 2010, 1, 31-38.

22. Gómez, J.D.M.; Ramírez, H.C.; Jasso, M.J.; Lopez, U.J. Variación en características reproductivas y germinación de semillas de Pinus leiophylla Schiede ex Schltdl. \& Cham. Rev. Fitotec. Mex. 2010, 33, 297-304.

23. Sánchez, T.V.; Nieto, P.M.; Mendizábal, L.D. Producción de semillas de Pinus cembroides subsp. orizabensis D.K. Bailey de Altzayanca, Tlaxcala, México. For. Veracruzana 2005, 7, 15-20.

24. Lemus, S.J.L. Maduración de Conos, Producción y Viabilidad de la Semilla de Pinus catarinae M.F. Robert-Passini. Bachelor Thesis, Universidad Autónoma Agraria Antonio Narro, Saltillo, México, 1999.

25. López, C.Y. Producción y Viabilidad de Semillas de Pinus johannis M.F. Robert en dos Poblaciones Naturales de México. Bachelor Thesis, Universidad Autónoma Agraria Antonio Narro, Saltillo, Mexico, June 2005.

26. SEMARNAT. Norma Oficial Mexicana NOM-059-SEMARNAT-2010, Protección Ambiental-Especies Nativas de México de Flora y Fauna Silvestres-Categorías de Riesgo y Especificaciones Para su Inclusión, Exclusión o Cambio-Lista de Especies en Riesgo; Diario Oficial de la Federación: Distrito Federal, México, 2014.

27. Farjon, A. Pinus rzedowskii and Pinus ayacahuite var. veitchii. The IUCN Red List of Threatened Species; Version 2015.2. Available online: http:/ / www.iucnredlist.org (accessed on 12 April 2013).

28. Delgado, V.P.; Rebolledo, V.; García, J.; Flores, C.; Piñero, D.; Vázquez, L.A. Aproximación Molecular Para la Evaluación Genética de Áreas Productoras de Semillas y de Conservación en Especies del Género Pinus; Informe Técnico; CONAFOR-CO1-176167; Comisión Nacional Forestal: Distrito Federal, México, 2014.

29. Delgado, V.P. Estructura Genética y Demográfica de una Especie del Género Pinus (Pinus rzedowskii Madrigal Et Caballero) Endémica de Michoacán, México. Master's Thesis, Universidad Nacional Autónoma de México, México City, Mexico, February 1997. 
30. Delgado, V.P.; Piñero, D.; Chaos, A.; Pérez, N.; Alvarez, E.R. High population differentiation and genetic variation in the endangered Mexican pine Pinus rzedowskii (Pinaceae). Am. J. Bot. 1999, 86, 669-676. [CrossRef] [PubMed]

31. Martínez, M. Los Pinos Mexicanos; Segunda Edición; Universidad nacional Autónoma de México: México City, Mexico, 1948; p. 361.

32. Aguirre, G.J.; Serna, C.H.N.; Villalobos, A.A.R.; Pérez, R.J.A.; Raes, N. Similar but not equivalent: Ecological niche comparison across closely-related Mexican White pines. Divers Distrib. 2015, 21, 245-257. [CrossRef]

33. Huerta, V.J. Estudio de conos y semillas de Pinus ayacahuite variedad veitchii Shaw en dos localidades de la Sierra Nevada de México. Bachelor Thesis, Universidad Autónoma Chapingo, Mexico, March 2000.

34. Flores, L.C.; López, U.J.; Vargas, H.J.J. Indicadores reproductivos en poblaciones naturales de Picea mexicana Martínez. Agrociencia 2005, 39, 117-126.

35. Sarvas, R. Investigations on the flowering and seed crop of Pinus sylvestris. Commun. Inst. For. Fenn. 1962, 53, $1-192$.

36. DeBarr, G.L.; Ebel, B.H. How seedbugs reduce the quantity and quality of pine seed yields. In Proceedings of the 12th Southern Forest Tree Improvement Conference, Baton Rouge, LA, USA, 12-13 June 1973; pp. 97-103.

37. Sorensen, F.C.; Miles, R.S. Self-pollination on Douglasfir and ponderosa pine seeds and seedlings. Silvae Genet. 1974, 23, 135-165.

38. Yazdani, R.; Lindgren, D. The impact of self-pollination on production of sound selfed seeds. In Biochemical Markers in the Population Genetics of Forest Trees; Fineschi, S., Malvolti, M.E., Cannata, F., Hattemer, H.H., Eds.; SPB Academic Publishing: The Hague, The Netherlands, 1991; pp. 143-147.

39. Kärkkäinen, K.; Savolainen, O. The degree of early inbreeding depression determines the selfing rate at the seed stage: Model and results from Pinus sylvestris (Scots pine). Heredity 1993, 71, 160-166. [CrossRef]

40. Fowler, D.P.; Park, Y.S. Population studies of white spruce. I. Effects of self-pollination. Can. J. For. Res. 1983, 13, 1133-1138. [CrossRef]

41. O'Connell, L.M.; Mosseler, A.; Rajora, O.P. Impacts of forest fragmentation on the reproductive success of white spruce (Picea glauca). Can. J. Bot. 2006, 84, 956-965.

42. Sánchez, V.N.; Martínez, P.A. Manual de Manejo y Propagación de Germoplasma Forestal; Universidad Michoacana de San Nicolás de Hidalgo: Morelia, Michoacán, Mexico, 2007.

43. Patterson, H.D.; Thompson, R. Recovery of inter-block information when block sizes are unequal. Biometrika 1971, 58, 545-554. [CrossRef]

44. Miller, R.G. Simultaneous Statistical Inference; Springer: New York, NY, USA, 1981.

45. SAS Institute. SAS/STAT Guide for Personal Computers; SAS Institute Inc.: Cary, NC, USA, 2013.

46. Sokal, R.R.; Rohlf, F.J. Biometry, 3rd ed.; Freeman: New York, NY, USA, 1995.

47. Hammer, Ø.; Harper, D.A.T.; Ryan, P.D. PAST: Paleontological Statistics Software Package for Education and Data Analysis. Paleontol. Electron. 2001, 4, 1-9.

48. Flores, L.C.; Jacobo, P.J.A.; Delgado, V.P. Producción de semillas de Pinus johannis M. F-Robert de tres poblaciones del Noreste de México. Rev. For. Baracoa 2016, under revision.

49. Ponce, M.A.; Bautista, H.C. Análisis de la producción de semillas de Pseudotsuga macrolepis Flous., en una plantación establecida en el municipio de Amecameca, estado de México. Bachelor Thesis, Universidad Autónoma Chapingo, México, Texcoco de Mora, Mexico, December 2008.

50. Ramírez, E.O.; Reyes, J.C.S.; Ramírez, J.M.; Cruz, J.H. Características de estructuras reproductivas en progenitores seleccionados de Pinus patula Schl. et Cham. For. Veracruzana. 2013, 15, 37-44.

51. Mápula, L.M.; López, U.J.; Vargas, H.J.J.; Hernández, L.A. Reproductive indicators in natural populations of Douglas-fir in Mexico. Biodivers. Conserv. 2007, 16, 727-742. [CrossRef]

52. Prieto, R.J.A.; Trujillo, R. Análisis de Conos y Semillas de Pinus engelmannii Carr., en el Municipio de Súchil, Dgo; Instituto Nacional de Investigaciones forestales, agrícolas y pecuarias: Mexico City, Mexico, 2006; Volume 1, pp. 49-50.

53. Williams, C.G. Selfed embryo death in Pinus taeda: A phenotypic profile. New Phytol. 2008, 178, $210-222$. [CrossRef] [PubMed]

54. Di-Giovanni, F.; Kevan, P.G.; Arnold, J. Lower planetary boundary layer profiles of atmospheric conifer pollen above a seed orchard in northern Ontario, Canada. For. Ecol. Manag. 1996, 83, 87-97. [CrossRef]

55. Savolainen, O.; Tanja, P.; Knurr, T. Gene flow and local adaptation in Trees. The annual review of ecology. Evol. Syst. 2007, 38, 595-619. [CrossRef] 
56. Frankham, R. Inbreeding and extinction: Island populations. Conserv. Biol. 1998, 12, 665-675. [CrossRef]

57. Lande, R. Genetics and demography in biological conserve. Science 1988, 241, 1455-1460. [CrossRef] [PubMed]

58. Ledig, F.T.; Jacob, C.V.; Hodgskiss, P.D.; Eguiluz, P.T. Recent evolution and divergence among populations of a rare Mexican endemic, Chihuahua spruce, following Holocene climatic warming. Evolution 1997, 51, 1815-1827. [CrossRef]

59. Owens, J.N.; Simpson, S.J.; Molder, M. Sexual reproduction of Pinus contorta. II. Postdormancy ovule, embryo, and seed development. Can. J. Bot. 1982, 60, 2071-2083. [CrossRef]

60. Owens, J.N.; Bennett, J.; Hirondelle, S.L. Pollination and cone morphology affect cone and seed production in lodgepole pine seed orchards. Can. J. Bot. 2005, 35, 383-400. [CrossRef]

61. Hamrick, J.L.; Godt, M.J.W.; Sherman, B.S.L. Gene flow among plant populations: Evidence from genetic markers. In Experimental and Molecular to Plant Biosystematics; Hoch, P.C., Stephenson, A.G., Eds.; Missouri Botanical Garden Press: St. Louis, MO, USA, 1995; pp. 215-232.

62. Delgado, V.P. Universidad Michoacana de San Nicolás de Hidalgo, Michoacán, Mexico. Personal communication, 2008.

63. Madrigal, S.X.; Caballero, D.M. Una nueva especie mexicana de Pinus. Mex. Inst. Nac. Invest. Forest Bol. Tec. 1969, 26, 1-11.

64. Saladin, B. Diversify or Specialize: Disturbances Influence Trait Evolution in Pinus. Master's Thesis, University of Zurich, Zurich, Switzerland, October 2013.

65. Gernandt, S.D.; Liston, A.; Piñero, D. Variation in the nrDNA ITS of Pinus subsection Cembroides: Implications for molecular systematic studies of pine species complexes. Mol. Phylogenet. Evol. 2001, 21, 449-476. [CrossRef] [PubMed]

66. Ganatsas, P.; Tsakaldimi, M.; Costas, T. Seed and cone diversity and seed germination of Pinus pinea in Strofyla site of the natural 2000 Network. Biodivers. Conserv. 2004, 17, 2427-2439. [CrossRef]

67. Negrete, N.R.; Universidad Michoacana de San Nicolas de Hidalgo, Michoacan, Mexico. Personal Communication, 2013.

68. Ayari, A.; Larbi, M.K. Ecophysiological variables influencing Aleppo pine seed and cone production: A review. Tree Physiol. 2014, 34, 426-437. [CrossRef] [PubMed]

69. Ledig, F.T. The conservation of diversity in forest trees: Why and how should genes be conserved. BioScience 1988, 38, 471-479. [CrossRef]

70. Mendoza, M.E.; Espino, E.J.; Quiñones, P.C.Z.; Flores, L.C.; Wehenkel, C.; Vargas, H.J.J.; Sáenz, R.C. Propuesta de conservación de tres especies mexicanas de Picea en peligro de extinción. Rev. Fitotec. Mex. 2015, 38, 235-247.

(C) 2016 by the authors; licensee MDPI, Basel, Switzerland. This article is an open access article distributed under the terms and conditions of the Creative Commons Attribution (CC-BY) license (http://creativecommons.org/licenses/by/4.0/). 